\title{
Phytochemical Characterization and Effect of Cagaita Leaf Extracts on Aspergillus Sp.
}

\author{
Rafael Pozzi Malheiros ${ }^{1}$ (D), Florisvalda da Silva Santos² (D), \\ Luciana Lucas Machado ${ }^{3}$ (D), Ana Maria Mapeli ${ }^{4}$
}

\begin{abstract}
${ }^{1}$ Departamento de Biologia Vegetal, Universidade Federal de Viçosa - UFV, Viçosa/MG, Brasil ${ }^{2}$ Centro de Formação em Ciências Ambientais, Universidade Federal do Sul da Bahia - UFSB, Porto Seguro/BA, Brasil ${ }^{3}$ Centro das Ciências Exatas e das Tecnologias, Universidade Federal do Oeste da Bahia - UFOB, Barreiras/BA, Brasil

${ }^{4}$ Centro das Ciências Biológicas e da Saúde, Universidade Federal do Oeste da Bahia - UFOB, Barreiras/BA, Brasil
\end{abstract}

\begin{abstract}
Fungi of the genus Aspergillus may promote damage to the physiological quality of forest seeds, and plant extracts have been used to control microflora associated with these seeds. Thus, the aim of the present work was to perform the phytochemical characterization of ethanolic and aqueous extracts obtained from Eugenia dysenterica leaves (cagaita), as well as to evaluate the effect of these extracts on the development of Aspergillus sp. isolated from Hymenaea stigonocarpa seeds (jatobá-do-cerrado). For this, qualitative phytochemical analysis of extracts was carried out and their effect on Aspergillus sp mycelial growth, sporulation and spore germination was evaluated. As a result, phenols, hydrolysable tannins, flavonols, flavanones, xanthones, flavones, free steroids and saponins were found in both extracts, which could be used in the search for new antifungal compounds in the treatment of stored forest seeds, since extracts have secondary compounds that allow inhibiting Aspergillus sp mycelial growth.
\end{abstract}

Keywords: Eugenia dysenterica, secondary metabolites, storage fungi. 


\section{INTRODUCTION}

Fungi are a diversified group of organisms that in addition to causing diseases in plants can also attack forest seeds during collection, processing and storage stages (Piña-Rodrigues et al., 2007). Among fungi that can influence the maintenance of the physiological quality of seeds, the genus Aspergillus stands out, as it deteriorates seeds making them unviable, being frequently found in seeds of forest species and having the capacity to cause embryo death (Santos et al., 2000; Cherobini et al., 2008). In this sense, protection strategies against fungi should be determined, thereby allowing maintenance of physiological quality and strength.

Chemical treatment by means of fungicides is generally the procedure used to control pathogens, aiming at improving seed performance. In literature, fungicides Benzimidazole, Dithiocarbonate, Captan, Rhodiauram and Monceren ${ }^{\circledR}$ (Vieira \& Gusmão, 2006; Silva et al., 2011) are the most widely used to treat forest seeds; however, the use of these products may not only damage human health, but also the environment.

In this context, extracts from medicinal plants have been used to control microflora associated with seeds, since these species have bioactive substances in their chemical composition that can act as fungicides (Souza et al., 2003; Carnelossi et al., 2009). Among species used for medicinal purposes, those belonging to the genus Eugenia (Fischer et al., 2005) should be highlighted.

The genus Eugenia is considered one of the largest in the Myrtaceae family, with approximately 500 tree and shrub species, playing a special role in providing extracts used as antimicrobial and anti-inflammatory agents, among others (Hussein et al., 2003). Studies with extract from Eugenia aromatica L. (cloves) have demonstrated antifungal activity against Fusarium sp. and Alternaria sp. fungi (Soatthiamroong et al., 2003).

Eugenia dysenterica DC. is popularly known as cagaita, and is a typical Cerrado tree widely used by the population due to its commercial and medicinal value (Giotto et al., 2007). Although there are studies that have demonstrated the biological activity of Eugenia species (Hussein et al., 2003; Soatthiamroong et al.,
2003), there are no reports in literature describing the fungitoxic activity of extracts from $E$. dysenterica on Aspergillus sp. leaves.

In this context, the aim of the present work was to perform the phytochemical characterization of the ethanolic and aqueous extracts obtained from E. dysenterica leaves, as well as to evaluate the effect of these extracts on the development of Aspergillus sp. isolated from Hymenaea stigonocarpa Mart. seeds (jatobá-do-cerrado).

\section{MATERIAL AND METHODS}

\subsection{Fungi isolates}

To isolate Aspergillus sp., H. stigonocarpa seeds were stored in a paper bag, placed in refrigerator and kept for three months. Seeds were distributed into Petri dishes (15 cm in diameter), 6 seeds per plate, containing filter paper moistened with autoclaved water, remaining in germination chamber at $25^{\circ} \mathrm{C}$ in the dark for five days until the appearance of the fungal colony around the seed. Subsequently, the colony was subcultured on plates containing Dextrose-Agar-Potato (DAP) culture medium and three days after, mycelial growth and fungal sporulation occurred. Then, colony fragments were successively subcultured until obtaining the pure culture and identification under optical microscope. After purification, a new assay was performed on plates containing DAP medium, which were incubated in Biological Oxygen Demand (BOD) incubator at $25^{\circ} \mathrm{C}$ in the dark.

\subsection{Acquisition of the plant material and preparation of aqueous and ethanolic extracts}

E. dysenterica plant material was obtained in Serra da Bandeira ( $-12^{\circ} 04^{\prime} 48^{\prime} \mathrm{S}$ and $\left.-45^{\circ} 00^{\prime} 36^{\prime \prime} \mathrm{W}\right)$ located in the city of Barreiras-BA during the morning at the end of August 2013. Botanical materials were collected and compared with exsiccate number 002362 deposited at the Herbarium of the Federal University of Western Bahia - BRBA/UFOB.

In order to prepare the ethanolic extract, shoot leaves were dried at room temperature, triturated and immersed in $92 \%$ ethanol for 48 hours; then, filtration was performed by discarding solids and removing the solvent in a rotary evaporator at 
temperature of approximately $70^{\circ} \mathrm{C}$ until product of pasty consistency was obtained. Distilled water was added to dried leaves to obtain the aqueous extract until the sample was covered and the solution was kept refrigerated at $10^{\circ} \mathrm{C}$ for 24 hours, thus avoiding fungal contamination. The material was subsequently filtered, frozen and lyophilized at $-35^{\circ} \mathrm{C}$. The aqueous extract was kept in desiccator until experiments were carried out.

\subsection{Phytochemical characterization of extracts obtained from $E$. dysenterica}

For detecting the main classes of secondary compounds, E. dysenterica leaf extracts were submitted to qualitative tests that result in color alteration and/or formation of characteristic precipitates for each class (Matos, 2009).

\subsection{Bioassays with Aspergillus sp.}

To perform bioassays, the aqueous extract was solubilized in distilled water and the ethanolic extract was solubilized in distilled water with $1 \%$ Dimethyl sulfoxide (DMSO). Extracts were subsequently sterilized by filtering in Milipore ${ }^{\circledast} 0.22 \mu \mathrm{m}$ membrane to eliminate possible contaminations and added to sterile and fluxing DAP culture medium in order to obtain final concentrations of $200,400,800,1600,3200,6400$ and $10000 \mathrm{mg} / \mathrm{L}$. The aqueous extract was compared to absolute control (sterilized distilled water), and the ethanolic extract was compared to absolute control and solubilizing control (sterilized distilled water + DMSO). The culture medium was poured onto Petri dishes of $9 \mathrm{~cm}$ in diameter, and inoculation was performed with discs of $0.5 \mathrm{~cm}$ in diameter containing mycelium of pure Aspergillus sp. colony. After being transferred to the center of the plate, discs were incubated in BOD-type growth chamber at $25^{\circ} \mathrm{C}$ in the dark for seven days (Silva \& Teixeira, 2012).

\subsubsection{Mycelial growth evaluation}

Aspergillus sp. mycelial growth was daily evaluated until the fungal colony reached the total diameter of the plate, and the colony radial growth was measured in three perpendicular lines drawn at the bottom of each Petri dish. The average values were used to estimate the vegetative development by calculating the area under the mycelial growth progression curve (AUMGPC), using the following Formula 1:

$$
A B M G P C=\sum((D+D a) / 2) * \mathrm{~T}
$$

Where: $\mathrm{D}$ represents the current mean diameter;

$\mathrm{Da}$ is the average diameter of the previous day;

and $\mathrm{T}$ is the time interval between the evaluation of the current mean diameter and the evaluation of the mean diameter of the previous day.

\subsubsection{Sporulation evaluation}

Suspensions were prepared for spore quantification by adding $10 \mathrm{~mL}$ of distilled water and sterilized by autoclaving Petri dishes containing the growing fungus to the point of the last vegetative growth evaluation. Then, the colony surface was scraped using Drigalski's loop to release spores and the obtained suspension was filtered on gauze. An aliquot of $15 \mu \mathrm{L}$ of the filtered suspension was placed in Neubauer chamber to estimate the number of spores/mL using optical microscope.

\subsubsection{Spore germination evaluation}

In order to evaluate the effect of $E$. dysenterica extracts on Aspergillus sp. germination, an aliquot of $1000 \mu \mathrm{L}$ of spore suspension and another of $400 \mu \mathrm{L}$ of each extract concentration were used. After homogenization, aliquots of $15 \mu \mathrm{L}$ of solution (spores + extract) were deposited on grooved slides, which were placed on Petri dishes containing filter paper moistened with $10 \mathrm{~mL}$ autoclaved distilled water. Subsequently, plates were incubated in $\mathrm{BOD}$ chamber at $25^{\circ} \mathrm{C}$ in the dark and the germination percentage was estimated after 12 hours of incubation by the analysis of slides under microscope. For each 100 quantified spores, spores showing germinating tube greater than or equal to their diameter were counted, which were considered germinated.

\subsection{Experimental design and statistical analysis}

Experiments followed a completely randomized design with four replicates, and the experimental unit consisted of three Petri dishes. The results were submitted to analysis of variance and means were compared by the Tukey test at $5 \%$ probability level using the SISVAR statistical software (Ferreira, 2008). 


\section{RESULTS AND DISCUSSION}

\subsection{Phytochemical characterization of extracts obtained from $E$. dysenterica}

The phytochemical evaluation of extracts from E. dysenterica leaves indicated the presence of several secondary compounds, and staining reactions were positive in both extracts for phenols, hydrolyzable tannins, flavonols, flavanones, flavanones, xanthones, flavones, free steroids and saponins (Table 1).

These groups of secondary metabolites may play an important ecological role for plants since they are involved in the defense system against pathogens, herbivores, and participate in plant-plant interactions acting as growth inhibitors or promoters (Taiz \& Zeiger,

Table 1. Phytochemical analysis of ethanolic (EEF) and aqueous (EAF) extracts obtained from Eugenia dysenterica leaves.

\begin{tabular}{lcc}
\multicolumn{1}{c}{$\begin{array}{c}\text { SECONDARY COMPOUND } \\
\text { CLASSES }\end{array}$} & EEF & EAF \\
Phenols & + & + \\
Condensed tannins & - & - \\
Hydrolysable tannins & + & + \\
Flavonols, flavanones, flavanonols and & + & + \\
xanthones & + & + \\
Flavones, flavonols and xanthones & + & + \\
Flavonols & + & + \\
Anthocyanins and anthocyanidins & - & - \\
Chalcones and auronas & - & - \\
\hline Free steroids & + & + \\
Saponins & + & + \\
\hline Triterpenoids & - & - \\
Quinones & - & - \\
\hline
\end{tabular}

+ Presence; - Absence.
2017). When using extracts from E. dysenterica plants collected in western Bahia, Malheiros et al. (2016) observed antioxidant and allelopathic activities for the species, making it promising for other studies with biological activity.

\subsection{Effect of ethanolic extract on the Aspergillus sp. development}

E. dysenterica ethanolic extract at concentration of $10000 \mathrm{mg} / \mathrm{L}$ promoted significant reduction of $1.8 \%$ on the area under the mycelial growth progression curve (AUMGPC) of Aspergillus sp., in comparison to absolute control (Table 2). However, this extract at concentration of $400 \mathrm{mg} / \mathrm{L}$ provided mean stimulus of $75 \%$ in sporulation compared to controls (Table 2), and a tendency to reduce sporulation was observed as the extract concentration increased.

Spore germination was also stimulated at extract concentrations of 800,1600 and $3200 \mathrm{mg} / \mathrm{L}$, with average increment of $55.7 \%$ in comparison to controls (Table 2), and a reduction trend at higher concentrations was also observed. This demonstrates the need to test higher extract concentrations or its fractionation at these concentrations to isolate and identify that the compound is responsible for the trend observed in the three biological variables evaluated in Aspergillus sp.

Some studies have shown that Aspergillus species are inhibited by essential oils and plant extracts; for example, Saju et al. (1998) used Curcuma longa L. essential oil (turmeric) and verified reduction of $73 \%$ in the Aspergillus sp. mycelial growth. Pereira et al. (2006) found reduction with Mentha piperita L. essential oil (peppermint), inhibiting 22.3\% the Aspergillus flavus

Table 2. Effect of the ethanolic extract from Eugenia dysenterica leaves on the area under the mycelial growth progression curve (AUMGPC), sporulation (SPO) and germination percentage (GERM\%) of Aspergillus sp. spores.

\begin{tabular}{|cccc}
\hline CONCENTRATION & AUMGPC & SPO & GERM\% \\
\hline $0 \mathrm{mg} / \mathrm{L}$ & $1897.4 \mathrm{~A}$ & $538.3 \mathrm{BC}$ & $23.9 \mathrm{C}$ \\
\hline $\mathrm{DMSO}$ & $1885.5 \mathrm{AB}$ & $531.9 \mathrm{BC}$ & $24.1 \mathrm{C}$ \\
\hline $200 \mathrm{mg} / \mathrm{L}$ & $1882.3 \mathrm{AB}$ & $870.6 \mathrm{AB}$ & $24.9 \mathrm{C}$ \\
\hline $400 \mathrm{mg} / \mathrm{L}$ & $1900.8 \mathrm{~A}$ & $939.8 \mathrm{~A}$ & $25.8 \mathrm{BC}$ \\
\hline $800 \mathrm{mg} / \mathrm{L}$ & $1884.1 \mathrm{~A}$ & $478.9 \mathrm{C}$ & $34.6 \mathrm{AB}$ \\
\hline $1600 \mathrm{mg} / \mathrm{L}$ & $1893.3 \mathrm{~A}$ & $354.6 \mathrm{C}$ & $37.7 \mathrm{~A}$ \\
\hline $3200 \mathrm{mg} / \mathrm{L}$ & $1896.1 \mathrm{~A}$ & $400.6 \mathrm{C}$ & $39.8 \mathrm{~A}$ \\
\hline $6400 \mathrm{mg} / \mathrm{L}$ & $1882.9 \mathrm{AB}$ & $334.4 \mathrm{C}$ & $28.1 \mathrm{BC}$ \\
\hline $10000 \mathrm{mg} / \mathrm{L}$ & $1863.1 \mathrm{~B}$ & $414.6 \mathrm{C}$ & $20.6 \mathrm{C}$ \\
\hline
\end{tabular}

Means followed by the same letters do not differ statistically from each other by the Tukey test at $5 \%$ significance level. 
mycelial growth. In turn, Venturoso et al. (2011) observed that Syzygium aromaticum L. aqueous extract (clove) completely inhibited the Aspergillus sp. mycelial growth. Nevertheless, there is no record in literature on the effect of $E$. dysenterica ethanolic extract, and the present work is the first to report these results related to fungus.

The fact that extracts stimulate fungal development may be associated with the presence of some growth promoting substance in plant extracts (Venturoso et al., 2011). Aspergillus species have their growth favored at high sugar concentrations (Pelczar et al., 1980). In line with this finding, it is worth mentioning that one of the components present in E. dysenterica leaves are saponins, which are formed by sugar chains (Bara et al., 2009). Based on the above, it could be suggested that saponins or other sugar-rich substances present in E. dysenterica ethanolic extract stimulated Aspergillus $s p$ sporulation and germination.

\subsection{Effect of aqueous extract on Aspergillus sp development}

The extract from E. dysenterica leaves provided reduction in mycelial growth when tested at concentrations of $1600,3200,6400$ and $10000 \mathrm{mg} / \mathrm{L}$, decreasing $13.3 ; 1,2 ; 2.5$ and $3.8 \%$, respectively, compared to control (Table 3).

Some studies with $E$. dysenterica have reported antifungal effect of extracts and essential oils on dermatophyte fungi such as Trichophyton rubrum and Cryptococcus neoformansi (Souza et al., 2002; Costa et al., 2000); however, there are no records of aqueous extracts inhibiting Aspergillus.

According to Gilles et al. (2010), antifungal activities can often be attributed to the presence of phenolic compounds and terpenoids, which are found in the vegetal extract of some species, since they have antimicrobial activity and act in the chemical defense of plants against fungi and bacteria. In the present work, these compounds were identified in E. dysenterica leaves, suggesting that the inhibitory effect on the Aspergillus sp. mycelial growth promoted by the aqueous extract may be associated with the presence of phenolic compounds.

In relation to Aspergillus sp. sporulation and germination, the aqueous extract had no significant effect at any concentration used (Table 3), but the effect of the extract on the inhibition and germination of Aspergillus spores was observed by Souza \& Soares (2014) using Allium sativum L. aqueous extract (garlic), with total reduction of Aspergillus niger sporulation. Germination inhibition is fundamental in the control of problems associated with fungi because this type of propagule is usually the starting point of the infection itself.

Thus, for the effective use of plant extracts, it is necessary that they not only inhibit pathogen mycelial growth, but also the germination of its spores. In this sense, the use of $E$. dysenterica crude aqueous extract in the control of Aspergillus sp. does not guarantee total efficacy, since the extract only had an effect on mycelial growth under the conditions of the present study, and did not influence the germination of fungus spores. However, performing new bioassays with fractions of this extract may provide more efficient results, since purified components generally have more significant effects.

The differences observed between the effect of ethanolic and aqueous extracts on the Aspergillus sp. development may be associated with the type of extractor

Table 3. Effect of the aqueous extract from Eugenia dysenterica leaves on the area under the mycelial growth progression curve (AUMGPC), sporulation (SPO) and germination percentage (GERM\%) of Aspergillus sp. spores.

\begin{tabular}{|cccc}
\hline CONCENTRATION & AUMGPC & SPO & GERM\% \\
\hline $0 \mathrm{mg} / \mathrm{L}$ & $1877.8 \mathrm{~A}$ & $214.6 \mathrm{~A}$ & $27.1 \mathrm{AB}$ \\
\hline $200 \mathrm{mg} / \mathrm{L}$ & $1858.6 \mathrm{AB}$ & $253.9 \mathrm{~A}$ & $38.3 \mathrm{AB}$ \\
\hline $400 \mathrm{mg} / \mathrm{L}$ & $1872.5 \mathrm{AB}$ & $482.7 \mathrm{~A}$ & $32.9 \mathrm{AB}$ \\
\hline $800 \mathrm{mg} / \mathrm{L}$ & $1867.1 \mathrm{AB}$ & $403.3 \mathrm{~A}$ & $29.1 \mathrm{AB}$ \\
\hline $1600 \mathrm{mg} / \mathrm{L}$ & $1626.1 \mathrm{E}$ & $355.1 \mathrm{~A}$ & $20.7 \mathrm{~B}$ \\
$3200 \mathrm{mg} / \mathrm{L}$ & $1855.2 \mathrm{~B}$ & $214.2 \mathrm{~A}$ & $39.8 \mathrm{~A}$ \\
\hline $6400 \mathrm{mg} / \mathrm{L}$ & $1831.2 \mathrm{C}$ & $295.6 \mathrm{~A}$ & $33.8 \mathrm{AB}$ \\
$10000 \mathrm{mg} / \mathrm{L}$ & $1805.9 \mathrm{D}$ & $236.5 \mathrm{~A}$ & $39.1 \mathrm{AB}$ \\
\hline
\end{tabular}

Means followed by the same letters do not differ statistically from each other by the Tukey test at $5 \%$ significance level. 
used in preparation of the aqueous extract, since each solvent has specific polarity, and the concentration of secondary metabolites is consequently different in each type of extract from the same plant (Salgado et al., 2013).

Therefore, although the same classes of metabolites were observed for both extracts, it is suggested that the water used for their preparation was able to extract specific inhibitory substances from larger amounts of E. dysenterica leaves compared to ethanol, but quantitative phytochemical tests should be carried out to prove this hypothesis.

Based on the results of this study, it was verified that the ethanolic extract is not recommended for treating seeds when it is aimed at controlling Aspergillus sp. as it favors fungal sporulation and germination. In turn, the aqueous extract can be used in the pre-treatment of forest seeds because it inhibits fungal mycelial growth. According to Medeiros et al. (2013), when treated with plant extracts, seeds predisposed to the action of fungi, showed higher longevity and germinative power, since they reduce the survival capacity of associated phytopathogens. In this way, it is important to propose/identify methods to treat seeds that allow reducing the initial inoculum of the disease when seeds are used.

\section{CONCLUSIONS}

Extracts from E. dysenterica leaves can be used in the search for new antifungal compounds for the treatment of stored forest seeds, since they contains secondary compounds that allow inhibiting Aspergillus sp. mycelial growth.

\section{SUBMISSION STATUS}

Received: 18 jan., 2017

Accepted: 19 feb., 2018

\section{CORRESPONDENCE TO}

\section{Rafael Pozzi Malheiros}

Departamento de Biologia Vegetal, Universidade Federal de Viçosa - UFV, Av. Peter Henry Rolfs, s/n, Campus Universitário, CEP 36570-000, Viçosa, MG, Brasil e-mail: rafaelpozzi@hotmail.com

\section{REFERENCES}

Bara MTF, Couto RO, Valgas AB, Paula JR. Caracterização físico-química do pó das folhas de Eugenia dysenterica DC. (Myrtaceae). Revista Eletrônica de Farmácia 2009; 6(1): 59-69.

Carnelossi PR, Schuwan-Estrada KRF, Cruz MES, Itako AT, Mesquini RM. Óleos essenciais no controle pós-colheita de Colletotrichum gloeosporioides em mamão. Revista Brasileira de Plantas Medicinais 2009; 11(4): 399-406. http://dx.doi.org/10.1590/S1516-05722009000400007.

Cherobini EAI, Muniz MFB, Blume E. Avaliação da qualidade da semente e mudas de cedro. Ciência Florestal 2008; 18(1): 65-73. http://dx.doi.org/10.5902/19805098511.

Costa TR, Fernandes OFL, Santos SC, Oliveira CMA, Lião LM, Ferri PH et al. Antifungal activity of volatile constituents of Eugenia dysenterica leaf oil. Journal of Ethnopharmacology 2000; 72(1-2): 111-117. http://dx.doi. org/10.1016/S0378-8741(00)00214-2. PMid:10967461.

Ferreira DF. SISVAR: um programa para análises e ensino de estatística. Revista Symposium 2008; 6(2): 36-41.

Fischer DCH, Limberger RP, Henriques AT, Moreno PRH. Essential oils from leaves of two Eugenia brasiliensis specimens from southeastern Brazil. The Journal of Essential Oil Research 2005; 17(5): 499-500. http://dx.doi.org/10.1 080/10412905.2005.9698977.

Gilles M, Zhao J, An M, Agboola S. Chemical composition and antimicrobial properties of essential oils of three Australian Eucalyptus species. Food Chemistry 2010; 119(2): 731-737. http://dx.doi.org/10.1016/j.foodchem.2009.07.021.

Giotto AC, Oliveira SCC, Silva JPG. Efeito alelopático de Eugenia dysenterica Mart. Ex DC. Berg. (Myrtaceae) na germinação e no crescimento de Lactuca sativa L. (Asteraceae). Revista Brasileira de Biociências 2007; 2(5): 600-602.

Hussein SAM, Hashem ANM, Seliem MA, Lindequist U, Nawwar MAM. Polyoxygenated flavonoids from Eugenia edulis. Phytochemistry 2003; 64(4): 883-889. http://dx.doi. org/10.1016/S0031-9422(03)00437-0. PMid:14559286.

Malheiros RP, Mapeli AM, Machado LL. Atividades antioxidante e alelopática de extratos foliares obtidos de Eugenia dysenterica. Ciência e Natura 2016; 38(2): 601609. http://dx.doi.org/10.5902/2179460X17421.

Matos FA. Introdução à fitoquímica experimental. Fortaleza: Edições UFC; 2009.

Medeiros JGF, Araujo AC No, Medeiros DS, Nascimento LC, Alves EU. Extratos vegetais no controle de patógenos em sementes de Pterogyne nitens Tul. Floresta e Ambiente 2013; 20(3): 384-390

Pelczar MJ, Reid R, Chan ECS. Microbiologia. São Paulo: McGraw-Hill; 1980. 
Pereira MC, Vilela GR, Costa LMAS, Silva RF, Fernandes AF, Fonseca EWN et al. Inibição do desenvolvimento fúngico através da utilização de óleos essenciais de condimentos. Ciência e Agrotecnologia 2006; 30(4): 731-738. http:// dx.doi.org/10.1590/S1413-70542006000400020.

Piña-Rodrigues FCM, Freire JM, Leles PSS, Breier TB. Parâmetros técnicos para produção de sementes florestais. Seropédica: Edur; 2007.

Saju KA, Venugopal MN, Mathew MJ. Antifungal and insect-repellent activities of essential oil of turmeric (Curcuma longa L.). Current Science 1998; 75(7): 660-662.

Salgado PC, Costa MF, Massocatto AM, Laverde A Jr, Frei F, Kolb RM et al. Avaliação do potencial citotóxico, moluscicida e alelopático dos extratos hidroetanólicos das folhas de Stryphnodendron obovatum Benth. Revista Brasileira de Biociências 2013; 11(2): 197-202.

Santos AF, Grigoletti A Jr, Auer CG. Transmissão de fungos por sementes de espécies florestais. Floresta 2000; 30(12): 119-128.

Silva JL, Teixeira RNV. Esporulação e crescimento micelial de Fusarium solani em diferentes meios de cultura e regimes de luminosidade. Revista Agroambiente 2012; 6(1): 47-52.

Silva LG, Cosmi FC, Jesus WC Jr, Souza AF, Moraes WB. Efeito do tratamento químico na sanidade de sementes de espécies florestais. Ciência Florestal 2011;21(3): 473-478. http://dx.doi.org/10.5902/198050983804.

Soatthiamroong T, Jatisatienr C, Supyen D. Antifungal activity of Eugenia aromatic (L.) Baill. (Myrtaceae) extract against some plant pathogenic molds. Acta Horticulturae 2003; 597(597): 209-214. http://dx.doi.org/10.17660/ ActaHortic.2003.597.29.

Souza AA, Bruno RLA, Araújo E, Bruno GB. Micoflora e qualidade fisiológica de sementes do algodoeiro tratadas com fungicidas químicos e extrato de aroeira. Revista Brasileira de Sementes 2003; 25(1): 56-64. http://dx.doi. org/10.1590/S0101-31222003000100010.

Souza LK, Oliveira CMA, Ferri PH, Santos SC, Oliveira JG Jr, Miranda ATBM et al. Antifungal properties of Brazilian Cerrado plants. Brazilian Journal of Microbiology 2002; 33(3): 247-249. http://dx.doi.org/10.1590/S151783822002000300012 .

Souza LSS, Soares ACF. Extrato aquoso de alho (Allium sativum L.) no controle de Aspergillus niger causador da podridão vermelha em sisal. Tecnologica (Chicago, Ill.) 2014; 17(2): 124-128.

Taiz L, Zeiger E. Fisiologia vegetal. 6. ed. Porto Alegre: Artmed; 2017.

Venturoso LR, Bacchi LMA, Gavassoni WL, Conus LA, Pontim BCA, Bergamin AC. Atividade antifúngica de extratos vegetais sobre o desenvolvimento de fitopatógenos. Summa Phytopathologica 2011; 37(1): 18-23. http://dx.doi. org/10.1590/S0100-54052011000100003.

Vieira FA, Gusmão E. Efeitos de giberelinas, fungicidas e do armazenamento na germinação de sementes de Genipa americana L. (Rubiaceae). Cerne 2006; 12(2): 137-144. 